\title{
Treatment of $\mathrm{Cd}^{2+}$ and $\mathrm{Cu}^{2+}$ Ions Using Modified Apatite Ore
}

\author{
Phuong Thu Nguyen $\mathbb{D}^{1},{ }^{1}$ Xuyen Thi Nguyen, ${ }^{1}$ Trang Van Nguyen, ${ }^{1,2}$ Thom Thi Nguyen $\mathbb{D},{ }^{1}$ \\ Thai Quoc Vu, ${ }^{1}$ Huy Trung Nguyen, ${ }^{1}$ Nam Thi Pham, ${ }^{1}$ and Thanh Mai Thi Dinh ${ }^{1,2,3}$ \\ ${ }^{1}$ Institute for Tropical Technology, Vietnam Academy of Science and Technology, 18 Hoang Quoc Viet, Cau Giay District, \\ Hanoi 10000, Vietnam \\ ${ }^{2}$ Graduate University of Science and Technology, Vietnam Academy of Science and Technology, 18 Hoang Quoc Viet, \\ Cau Giay District, Hanoi 10000, Vietnam \\ ${ }^{3}$ University of Science and Technology of Hanoi, Vietnam Academy of Science and Technology, 18 Hoang Quoc Viet, \\ Cau Giay District, Hanoi 10000, Vietnam
}

Correspondence should be addressed to Phuong Thu Nguyen; phuongvktnd@gmail.com

Received 28 December 2019; Revised 23 February 2020; Accepted 28 February 2020; Published 26 March 2020

Academic Editor: Mohammad A. Al-Ghouti

Copyright (c) 2020 Phuong Thu Nguyen et al. This is an open access article distributed under the Creative Commons Attribution License, which permits unrestricted use, distribution, and reproduction in any medium, provided the original work is properly cited.

\begin{abstract}
Apatite ore from Lao Cai (Vietnam) has large reserves and low prices. Its main component is fluorapatite. The purification and modification of apatite ore can produce a material that can be used as an absorbent for heavy metals with high efficiency. The molecular structure, phase component, specific surface area, element component, and morphology of modified apatite ore from Lao Cai province, Vietnam, were characterized by IR, XRD, BET, EDX, and SEM methods. The IR and XRD results show that the modified process transformed apatite ore from fluorapatite to nanohydroxyapatite. The specific surface area of modified apatite ore $\left(100.79 \mathrm{~m}^{2} / \mathrm{g}\right)$ is much higher than the original ore $\left(3.97 \mathrm{~m}^{2} / \mathrm{g}\right)$. The modified apatite ore was used to adsorb $\mathrm{Cd}^{2+}$ and $\mathrm{Cu}^{2+}$ ions in water. The effect of adsorbent mass, $\mathrm{pH}$, contact time, and initial concentration of $\mathrm{Cd}^{2+}$ and $\mathrm{Cu}^{2+}$ on the adsorption efficiency and capacity was investigated. Besides, the isotherm adsorption model was determined using Freundlich and Langmuir theories.
\end{abstract}

\section{Introduction}

Nowadays, water pollution caused by heavy metal is a serious problem for human health and the environment. Heavy metal poisoning will lead to many fatal diseases such as pulmonary edema, kidney failure, cancer. Especially, a high concentration of cadmium $(\mathrm{Cd})$ and copper $(\mathrm{Cu})$ can affect the nervous and skeletal system [1-3]. The content of heavy metal ions in drinking water is very low, maximum content of Pb: $0.05 \mathrm{mg} / \mathrm{L} ; \mathrm{Hg}$ : $0.006 \mathrm{mg} / \mathrm{L}$; As: $0.01 \mathrm{mg} / \mathrm{L}$; Cd: $0.003 \mathrm{mg} / \mathrm{L} ; \mathrm{Cr}: 0.05 \mathrm{mg} / \mathrm{L} ; \mathrm{Mn}: 0.1 \mathrm{mg} / \mathrm{L} ; \mathrm{Cu}: 2 \mathrm{mg} / \mathrm{L}$ following WHO standard [4].

Heavy metal ions can be removed by many methods using different materials such as activated carbon, zeolite, clay, silica, polymer, and apatite [3,5-7]. Apatite includes hydroxyapatite $\left(\mathrm{Ca}_{5}\left(\mathrm{PO}_{4}\right)_{3}(\mathrm{OH})\right.$, fluorapatite $\mathrm{Ca}_{5}\left(\mathrm{PO}_{4}\right)_{3} \mathrm{~F}$, and chlorapatite $\mathrm{Ca}_{5}\left(\mathrm{PO}_{4}\right)_{3} \mathrm{Cl}$. Hydroxyapatite powder can remove some pollution ions and substances in water such as
$\mathrm{Cu}^{2+}, \mathrm{Pb}^{2+}, \mathrm{Zn}^{2+}, \mathrm{Cd}^{2+}, \mathrm{Co}^{2+}, \mathrm{Cr}^{6+}, \mathrm{La}^{3+}, \mathrm{Eu}^{3+}$, phenol, nitrobenzene, $\mathrm{NO}_{3}{ }^{-}, \mathrm{F}^{-}$[6-17], and Congo Red [18] with high adsorption ability. Hydroxyapatite can be synthesized by many methods from different calcium and phosphorus sources.

One of the research directions of environmental technology is finding the natural original materials with huge reserves, low price, and good treatment ability [19-21]. Using apatite ore for treating heavy metals in soil is applied in many countries in the world, such as in situ remediation techniques and phosphate-induced metal stabilization. Apatite can treat almost heavy metals and radioactive substances such as $\mathrm{Cu}, \mathrm{As}, \mathrm{Zn}, \mathrm{Th}, \mathrm{Ac}, \mathrm{U}, \mathrm{Pu}, \mathrm{Sr}, \mathrm{Cd}, \mathrm{Se}, \mathrm{Cs}$, $\mathrm{Tc}$, and $\mathrm{Pb}$ to prevent the pollution to the water [22-28]. $\mathrm{PO}_{4}{ }^{3-}$ groups in apatite can react with heavy metals to form precipitation and $\mathrm{Ca}^{2+}$ ions in the structure of apatite can be replaced by heavy metals ions [29]. Moroccan phosphate rock which has component is carbonate-fluorapatite was 
used as the calcium and phosphorus source to synthesize nanohydroxyapatite. This modified material removed heavy metal ions such as $\mathrm{Pb}^{2+}, \mathrm{Cu}^{2+}$, and $\mathrm{Zn}^{2}$ with a higher adsorption capacity than natural rock $[30,31]$. Spongy Ni/Fe carbonate-fluorapatite was synthesized from natural phosphorite (Egypt) that was studied for decontamination of $\mathrm{Zn}^{2+}, \mathrm{Co}^{2+}$, and $\mathrm{Cu}^{2+}$ with $Q_{\max }$ values of $149.25 \mathrm{mg} / \mathrm{g}$, $106.4 \mathrm{mg} / \mathrm{g}$ and $147.5 \mathrm{mg} / \mathrm{g}$, respectively [3].

In Vietnam, apatite from Lao Cai has a huge reserve of about 2550 million tons. The main component of the material is fluorapatite which is used to procedure fertilizer for agriculture. Using this material to adsorb heavy metal ions such as $\mathrm{Cd}^{2+}, \mathrm{Cu}^{2+}$ is still limited.

In this study, apatite ore was modified by a chemical process and its characterization was analyzed using IR, XRD, EDX, SEM, and BET methods. After that, the material was used to treat $\mathrm{Cd}^{2+}$ and $\mathrm{Cu}^{2+}$ ions in water and investigated the effect of contact time, initial $\mathrm{Cd}^{2+}$ and $\mathrm{Cu}^{2+}$ concentration, $\mathrm{pH}$ solution, and adsorbent mass on adsorption capacity and efficiency. From the experiment data, the adsorption isotherms were also determined.

\section{Materials and Methods}

2.1. Materials. Apatite ore is a product from Lao Cai province, Vietnam. Apatite ore was milled and dried at $100^{\circ} \mathrm{C}$ in the oven. And then, it was modified by the procedure as follows: apatite ore was put in the glass reactor containing $1 \mathrm{M} \mathrm{HNO}_{3}$ solution and was stirred at a rate of $400 \mathrm{rpm}$ at room temperature. After that, the insoluble matter was separated by filtration. The remaining solution containing $\mathrm{Ca}^{2+}$ and $\mathrm{PO}_{4}{ }^{3-}$ is neutralized by a concentrated $\mathrm{NH}_{4} \mathrm{OH}$ solution $(25 \%)$ to form precipitation of hydroxyapatite. The $\mathrm{pH}$ value was maintained at $\mathrm{pH}>10$ to avoid the formation of other calcium phosphate compounds. The powder of hydroxyapatite was obtained by filtration and washed by distilled water to $\mathrm{pH}$ value of 7 to remove the unreacted calcium, phosphate, or ammonia ions, and then dried at $100^{\circ} \mathrm{C}$.

$\mathrm{NaOH} 96 \%, \mathrm{KCl} 99.5 \%, \mathrm{HCl} 36 \%, \mathrm{NH}_{3} 25 \%, \mathrm{HNO}_{3} 65 \%$, $\mathrm{CuSO}_{4} \cdot 5 \mathrm{H}_{2} \mathrm{O} 99 \%$ are pure chemicals from China; $\mathrm{Cd}\left(\mathrm{NO}_{3}\right)_{2} \cdot 4 \mathrm{H}_{2} \mathrm{O} 99.5 \%$ is pure chemical of Merck.

Apatite and modified apatite ore characterized the molecular structure, phase component, morphology, specific surface area, and element component by Infrared (IR, Nicolet iS10, Thermo Scientific), Scanning Electron Microscope (SEM-EDX, SM-6510LV, Jeol-Japan, X-Act, Oxford Instrument-England and Hitachi S-4800-Japan), Highresolution Transmission Electron Microscope (HR-TEM, JEM2100, Jeol-Japan), X-ray Diffraction (XRD, D8 ADVANCE-Bruker, CuK $\mathrm{K}_{\alpha}$ radiation $(\lambda=1.54056 \AA)$ with a step angle of $0.030^{\circ}$, the scanning rate of $0.04285 \mathrm{~s}^{-1}$, and $2 \theta$ degree in the range of $10-70^{\circ}$ ) and Brunauer-Emmett-Teller methods (BET, TriStar II, Micromerit, $77 \mathrm{~K}, \mathrm{~N}_{2}$ ).

2.2. Adsorption Experiments. The adsorption experiments of $\mathrm{Cd}^{2+}$ and $\mathrm{Cu}^{2+}$ ions were conducted with $50 \mathrm{~mL}$ of $\mathrm{Cd}\left(\mathrm{NO}_{3}\right)_{2}$ or $\mathrm{CuSO}_{4}$ solution at different concentrations from $10 \mathrm{mg} / \mathrm{L}$ to $1000 \mathrm{mg} / \mathrm{L}$. An amount of modified apatite ore from $0.01 \mathrm{~g}$ to $0.1 \mathrm{~g}$ was dispersed into the above solution. Initial $\mathrm{pH}$ values of solution were adjusted from 2.5 to 8 using solutions of $0.01 \mathrm{M} \mathrm{KOH}$ and $0.01 \mathrm{M} \mathrm{HCl}$ and controlled by $\mathrm{pH}$ meter (1100H VWR pHenomenal, Germany). The mixtures were stirred at a rate of $400 \mathrm{rpm}$ by a magnetic stirrer (Velp Scientifica) at different times (from 5 to 90 minutes). The concentration of $\mathrm{Cd}^{2+}$ and $\mathrm{Cu}^{2+}$ ions in the solutions after treatment was determined by Atomic $\mathrm{Ab}$ sorption Spectrophotometer (AAS) on iCE 3500 Thermo Scientific device (Germany).

The adsorption efficiency $(H(\%))$ and capacity $(Q(\mathrm{mg} / \mathrm{g}))$ were calculated according to the following equation:

$$
\begin{aligned}
& H=\left(C_{\mathrm{o}}-C_{\mathrm{e}}\right) \cdot \frac{100}{C_{\mathrm{o}}}, \\
& Q=\left(C_{\mathrm{o}}-C_{\mathrm{e}}\right) \frac{V}{m},
\end{aligned}
$$

where $C_{\mathrm{o}}(\mathrm{mg} / \mathrm{L})$ is the initial concentration of $\mathrm{Cd}^{2+}$ and $\mathrm{Cu}^{2+}$ ions in the solution, $C_{\mathrm{e}}(\mathrm{mg} / \mathrm{L})$ is the equilibrium concentration of $\mathrm{Cd}^{2+}$ and $\mathrm{Cu}^{2+}$ ions in the solution after treatment, $V(\mathrm{~L})$ is the solution volume $(V=50 \mathrm{~mL})$, and $m$ $(\mathrm{g})$ is the mass of modified apatite ore.

\section{Results and Discussion}

3.1. Characterization of Original and Modified Apatite Ore. The infrared spectra and the SEM and TEM images of apatite ore and modified apatite ore are presented in Figures 1 and 2, respectively. The spectra show that characteristic bands of $\mathrm{PO}_{4}{ }^{3-}$ at $1097,1046,600$, and $564 \mathrm{~cm}^{-1}$ correspond to the asymmetric stretching vibration of the $\mathrm{P}-\mathrm{O}$ bond and the asymmetric bending vibration of O-P-O, respectively [32]. The peak with strong intensity at $3417 \mathrm{~cm}^{-1}$ is characteristic for the vibration of the $\mathrm{OH}^{-}$group or the absorbed water. In addition, the bending vibration of the $\mathrm{OH}^{-}$group is also characterized by a peak at wave number of $1617 \mathrm{~cm}^{-1}$. The peak at $696 \mathrm{~cm}^{-1}$ which is between 674 and $720 \mathrm{~cm}^{-1}$, is typical for $\mathrm{F}^{-}$ion [33]. Besides, there are peaks at 1458 and $1426 \mathrm{~cm}^{-1}$ that correspond to the vibration of $\mathrm{CO}_{3}{ }^{2-}$ group [32]. The peak at $1384 \mathrm{~cm}^{-1}$ in modified apatite is attributed to $\mathrm{NO}_{3}{ }^{-}$group [34] in the modification process. It is important to note that there were no visible characteristic peaks for $\mathrm{F}^{-}$and $\mathrm{CO}_{3}{ }^{2-}$ after modifying, indicating that the modified process has transformed fluorapatite in the apatite ore to hydroxyapatite. This will be confirmed by the XRD result below.

From SEM images, it can be seen that the particles of apatite ore do not have a uniform particle size. The size of large particles can be up to $15-20 \mu \mathrm{m}$. The smallest particles are about $200 \mathrm{~nm}$. After modifying, the particles are more uniform in size and significantly smaller than those before modifying with nanoscale. TEM images of modified apatite ore reflected concordance with the results obtained from SEM images. From TEM images, we can see that the cylinder particles are cluster and have a size of about $20-30 \mathrm{~nm}$.

To determine the crystallinity and phase composition, the samples of apatite ore before and after modifying are 


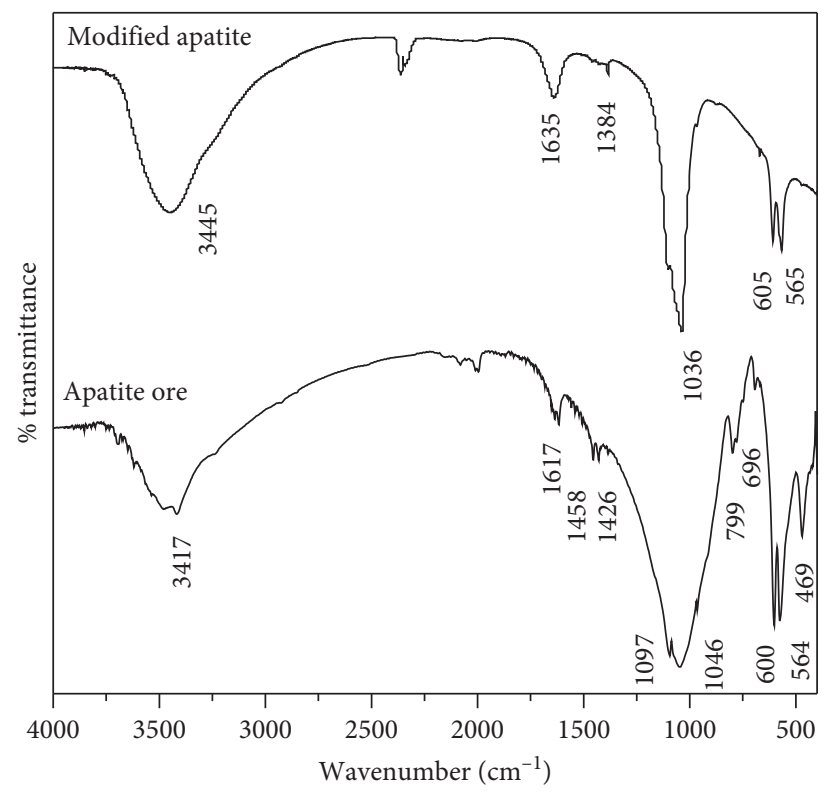

FIGURE 1: FT-IR spectra of apatite ore before (a) and after (b) modifying.

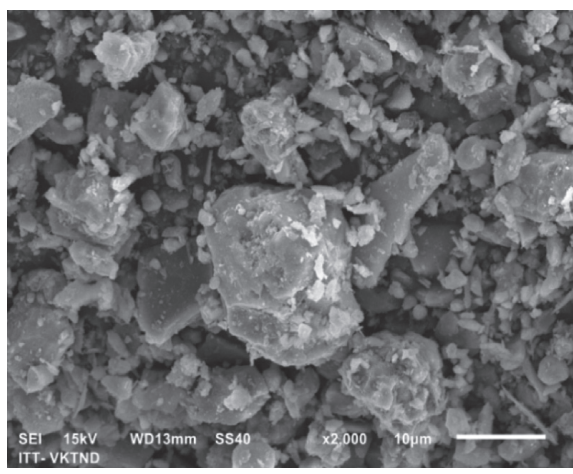

(a)

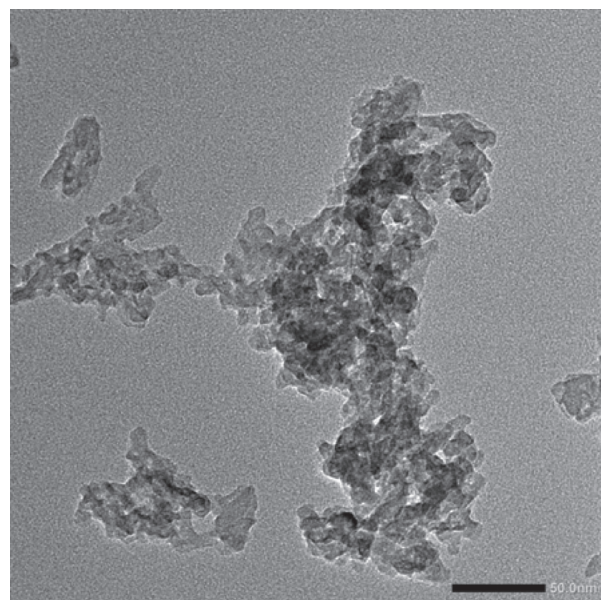

(c)

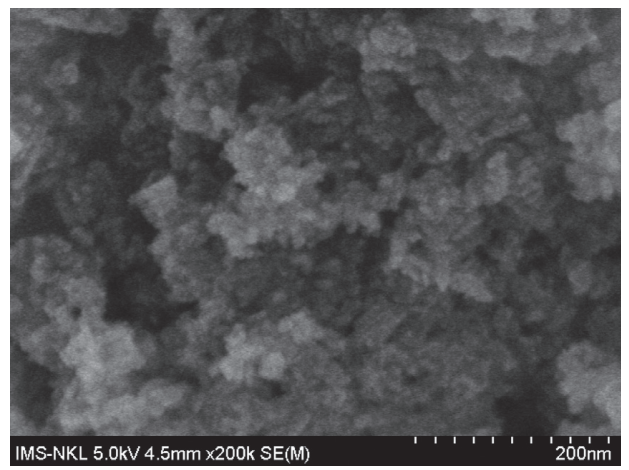

(b)

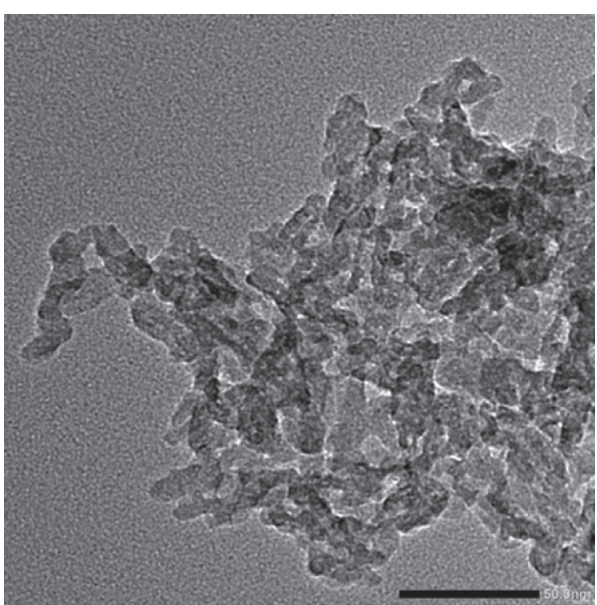

(d)

FIGURE 2: SEM images of apatite ore before (a) and after (b) modifying and TEM images of modified apatite ore (c, d).

characterized by X-ray diffraction (Figure 3). On the X-ray diffraction pattern of apatite ore, there are typical peaks for the phase of fluorapatite and some other peaks specific to
$\mathrm{SiO}_{2}$ and $\mathrm{Ca}_{2}\left(\mathrm{Al}_{2} \mathrm{O}_{7}\right)_{2}$. The diffraction angle $(2 \theta)$ of $32^{\circ} ; 33^{\circ}$; $34^{\circ}$ specific to the phase of $\mathrm{Ca}_{5}\left(\mathrm{PO}_{4}\right)_{3} \mathrm{~F}$. There are also some other peaks corresponding to the phase of $\mathrm{Ca}_{5}\left(\mathrm{PO}_{4}\right)_{3} \mathrm{~F}$ with 


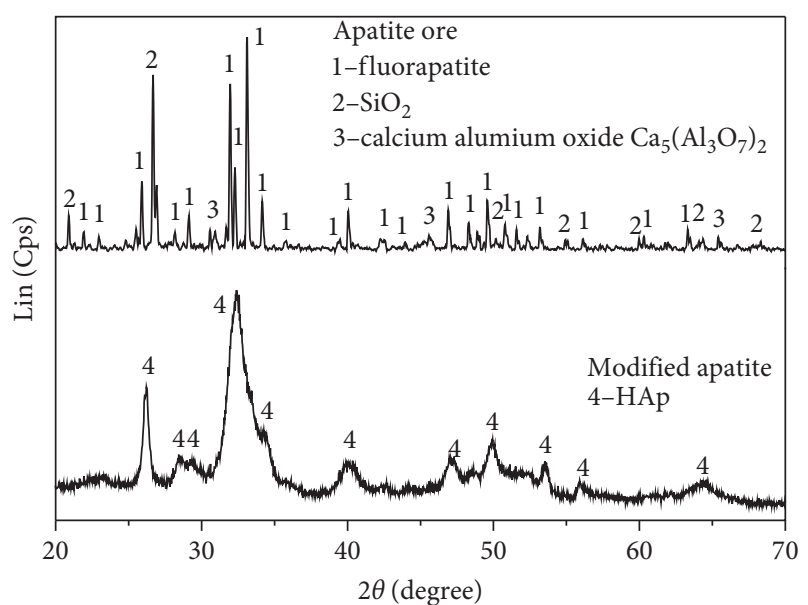

Figure 3: X-ray diffraction patterns of apatite ore before and after modifying.

smaller intensity at $2 \theta$ of $11^{\circ} ; 26^{\circ} ; 36^{\circ} ; 40^{\circ} ; 47^{\circ} ; 50^{\circ} \ldots$. PDF $00-015-0876,32]$. The phase of $\mathrm{SiO}_{2}$ is characterized by the peaks at $21.0^{\circ}$ and $26.7^{\circ}$ [PDF 00-046-1045] and $\mathrm{Ca}_{2}\left(\mathrm{Al}_{2} \mathrm{O}_{7}\right)_{2}$ crystal is attributed at $2 \theta$ of $31^{\circ}$ [PDF 01-070-0801]. The $\mathrm{X}$-ray diffraction pattern shows that the phase composition of the ore sample is mainly fluorapatite and also contains $\mathrm{SiO}_{2}$ and a small content of $\mathrm{Ca}_{2}\left(\mathrm{Al}_{2} \mathrm{O}_{7}\right)_{2}$. For modified apatite ore samples, the characteristic peaks for hydroxyapatite were observed at $2 \theta$ of 26.5 and $32.4^{\circ}$ corresponding to the (002) and (211) crystal planes [16]. This proves again that the modified process has transformed fluorapatite in the ore to hydroxyapatite.

The specific surface area of apatite and modified apatite ore is determined by the BET method, using $\mathrm{N}_{2}$ adsorption at $77 \mathrm{~K}$ (Figure 4). The $\mathrm{N}_{2}$ adsorption/desorption isotherm and the pore size distributions were plotted in Figures 4(a) and 4(b). According to the IUPAC classification of pores materials, both apatite and modified apatite exhibit type IV isotherm curve with a hysteresis loop, which indicates the presence of mesopores [19]. The average pore size of apatite ore and modified apatite is $15.88 \mathrm{~nm}$ and $24.10 \mathrm{~nm}$, respectively. The results show that the apatite ore sample has a lower significant adsorption capacity of $\mathrm{N}_{2}$ than the modified sample. The specific surface area for apatite ore before and after modifying is 3.97 and $100.79 \mathrm{~m}^{2} / \mathrm{g}$, respectively. This result can predict that the modified apatite ore may have better adsorption capacity than the original apatite.

The composition and percentage of elements in apatite ore are in accordance with the published company production criteria and the XRD results. The EDX results are presented in Figure 5 and Table 1. EDX spectra show the characteristic peaks for elements of $\mathrm{Ca}, \mathrm{P}, \mathrm{O}, \mathrm{F}$ in apatite ore. Besides, there are several metal elements with small components such as $\mathrm{Al}, \mathrm{K}, \mathrm{Fe}, \mathrm{Mn}$. For the modified apatite sample, the peaks of $\mathrm{Ca}, \mathrm{P}$, and $\mathrm{O}$ were observed, along with other elements with small components. The ratios of $\mathrm{Ca} / \mathrm{P}$ for apatite before and after modifying are 1.53 and 1.60 , respectively, similar to that in fluorapatite $\mathrm{Ca}_{5}\left(\mathrm{PO}_{4}\right)_{3} \mathrm{~F}$ and hydroxyapatite $\mathrm{Ca}_{5}\left(\mathrm{PO}_{4}\right)_{6}(\mathrm{OH})_{2}(1.67)$. For solids after filtering, while the content of $\mathrm{Ca}, \mathrm{P}$ is very small (about 0.44 and $0.92 \%$ by weight), the data for $\mathrm{Si}$ is significantly large (33.65\% by weight), indicating that the solids contain mainly $\mathrm{SiO}_{2}$.

\subsection{Adsorption Experiments Results}

3.2.1. Calibration Curve. Several solutions with an initial $\mathrm{Cd}^{2+}$ concentration of $0.24-2 \mathrm{mg} / \mathrm{L}$ and $\mathrm{Cu}^{2+}$ from $0.12-8 \mathrm{mg} / \mathrm{L}$ prepared from a $1000 \mathrm{mg} / \mathrm{L}$ standard solution were used to build the calibration curve of $\mathrm{Cd}^{2+}$ and $\mathrm{Cu}^{2+}$ by AAS method (Figure 6). The calibration curve equation $y=0.21208 x$ with correlation coefficient $R^{2}=0.9993$ and $y=0.0693 x$ with $R^{2}=0.9993$ used to calculate the concentrations of $\mathrm{Cd}^{2+}$ and $\mathrm{Cu}^{2+}$, respectively, in the next experiments.

3.2.2. Effect of the Modified Apatite Mass. The influence of modified apatite ore mass on the adsorption capacity and efficiency of $\mathrm{Cd}^{2+}$ and $\mathrm{Cu}^{2+}$ was shown in Figure 7. The results show that when the mass of modified apatite increases, the adsorption efficiency increases and the adsorption capacity decreases. For $\mathrm{Cd}^{2+}$ (Figure 7(a)), treatment efficiency increased rapidly from $39.64 \%$ to $82.08 \%$ when the modified apatite mass increased from $0.01 \mathrm{~g}$ to $0.05 \mathrm{~g}$. After that, the adsorption efficiency increases slowly in the range of adsorbent mass from $0.05 \mathrm{~g}$ to $0.1 \mathrm{~g}$. Therefore, to achieve not only a relatively high treatment efficiency but also high adsorption capacity, $0.05 \mathrm{~g}$ modified apatite is selected for further experiments. Similarly, for the treatment of $\mathrm{Cu}^{2+}$ ion, $0.03 \mathrm{~g}$ modified apatite is appropriate.

3.2.3. Effect of Solution $p H$. To determine $\mathrm{pH}_{\mathrm{pzc}}, 50 \mathrm{~mL}$ solution $0.01 \mathrm{M} \mathrm{KCl}$ was adjusted $\mathrm{pH}$ in the broad $\mathrm{pH}$ range from 5 to 9 ( $\mathrm{pH}_{\text {before }}$ ) and in the small $\mathrm{pH}$ range from 7 to 8 by $0.01 \mathrm{M} \mathrm{KOH}$ and $0.01 \mathrm{M} \mathrm{HCl}$ solution. $0.03 \mathrm{~g}$ modified apatite was put in the solution, stir 1 hour with rate $400 \mathrm{rpm}$ at room temperature. Filter and measure the $\mathrm{pH}$ value of the obtained solution $\left(\mathrm{pH}_{\mathrm{after}}\right)$. The curve of $\Delta \mathrm{pH}\left(=\mathrm{pH}_{\mathrm{after}}-\right.$ $\mathrm{pH}_{\text {before }}$ ) follows $\mathrm{pH}_{\text {before }}$ and horizontal axis meet at $\mathrm{pH}_{\mathrm{pzc}}$. The result of determining the $\mathrm{pH}$ value at the point zerocharge of the modified apatite ore is shown in Figure 8. The result shows that the adsorbent has point zero-charge at $\mathrm{pH}_{\mathrm{pzc}}=7.49$.

The effect of $\mathrm{pH}$ on the adsorption efficiency and capacity of modified apatite ore is shown in Figure 9. The results show that when the $\mathrm{pH}$ of the solution increased from 2.6 to 7.9 , the adsorption efficiency and capacity increased. At low $\mathrm{pH}$ values, the surface of the material has a positive charge; therefore the interactive force is also electrostatic force. Besides, if the concentration of $\mathrm{H}^{+}$ions is high, the competition with metal cations in the adsorption process leads to a decrease in efficiency. When $\mathrm{pH}$ is higher than $\mathrm{pH}_{\mathrm{pzc}}$ (7.49), the adsorption capacity and efficiency rise. It can be explained as follows: at high $\mathrm{pH}$ value, the surface of adsorbent has a negative charge, but if $\mathrm{pH}$ is too high, the precipitation of $\mathrm{Cd}(\mathrm{OH})_{2}$ and $\mathrm{Cu}(\mathrm{OH})_{2}$ can happen $[2,3,15]$. To facilitate the practical application, we choose 


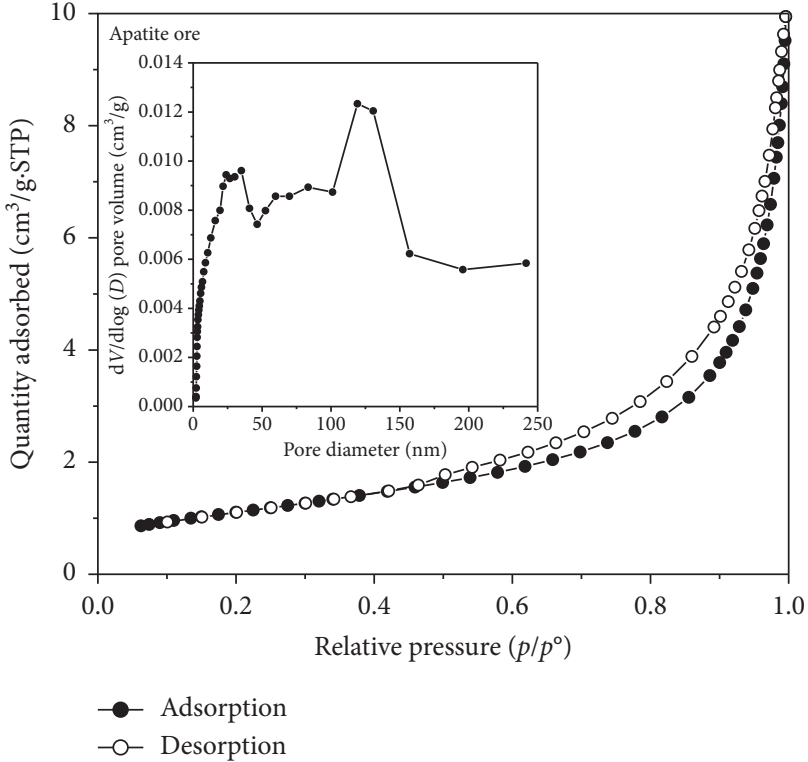

(a)

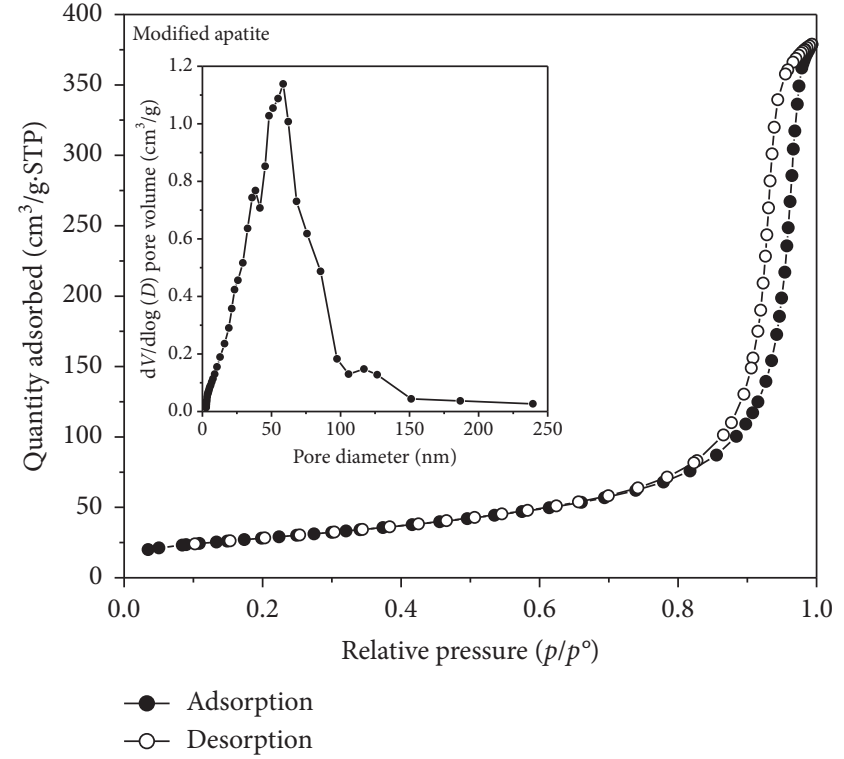

(b)

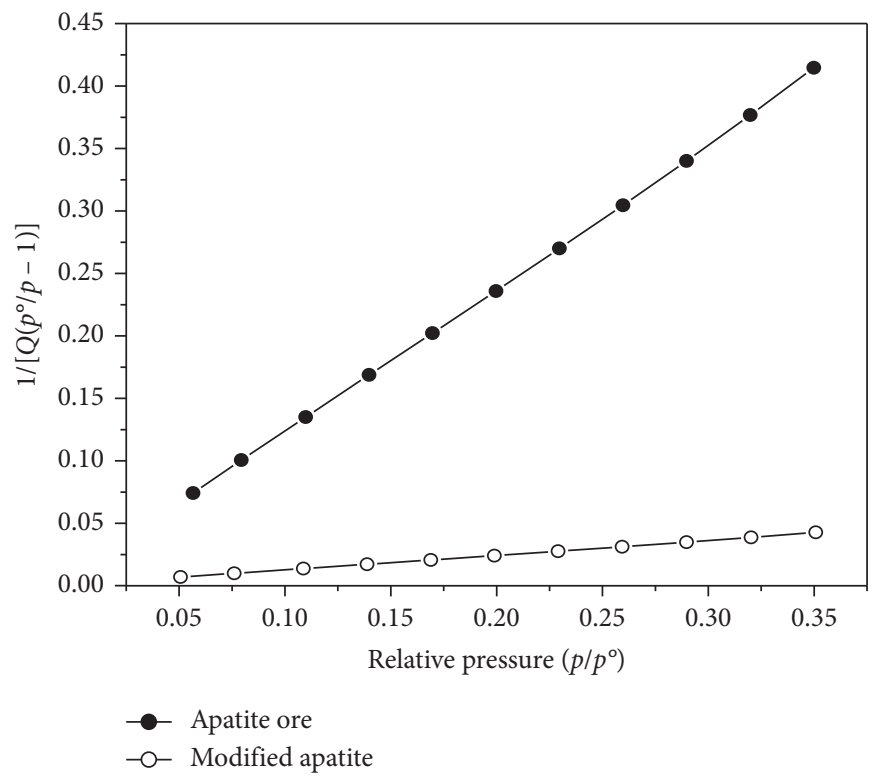

(c)

Figure 4: The $\mathrm{N}_{2}$ adsorption-desorption isotherm and the pore size distributions of apatite ore (a), modified apatite (b), and BETplot (c) of apatite ore before and after modifying.

$\mathrm{pH}=\mathrm{pHo}=5.5\left(\right.$ for $\left.\mathrm{Cd}^{2+}\right)$ and $5.6\left(\right.$ for $\left.\mathrm{Cu}^{2+}\right)$ to investigate the next experiments.

3.2.4. Effect of Contact Time. The variation of the adsorption capacity and efficiency according to the contact time was investigated with the conditions as follows: the adsorbent mass is $0.05 \mathrm{~g}$ modified apatite ore for $\mathrm{Cd}^{2+}$ adsorption and $0.03 \mathrm{~g}$ for $\mathrm{Cu}^{2+}$ adsorption, in $50 \mathrm{~mL}$ of the $\mathrm{Cd}^{2+}$ or $\mathrm{Cu}^{2+}$ solution $(30 \mathrm{mg} / \mathrm{L}), \mathrm{pH}_{\mathrm{o}}$, at $25^{\circ} \mathrm{C}$ with the different contact time changed from 5 to 90 minutes (Figure 10).
When increasing the adsorption time from 5 to 30 minutes, the $\mathrm{Cd}^{2+}$ adsorption efficiency increased significantly from $50 \%$ to $84 \%$, corresponding to the increase of adsorption capacity from $14.15 \mathrm{mg} / \mathrm{g}$ to $24.24 \mathrm{mg} / \mathrm{g}$. From 30 minutes to 60 minutes, the adsorption efficiency and capacity increase gradually. It can be explained that when the adsorption time increases, the ions fill the pores of the absorbent more, thus the adsorption efficiency and capacity increase. However, after a certain time, the adsorption equilibrium is reached, the adsorption capacity remains stable. Therefore 30 minutes is the optimal $\mathrm{Cd}^{2+}$ adsorption time of the modified apatite ore. Similarly, for the adsorption 


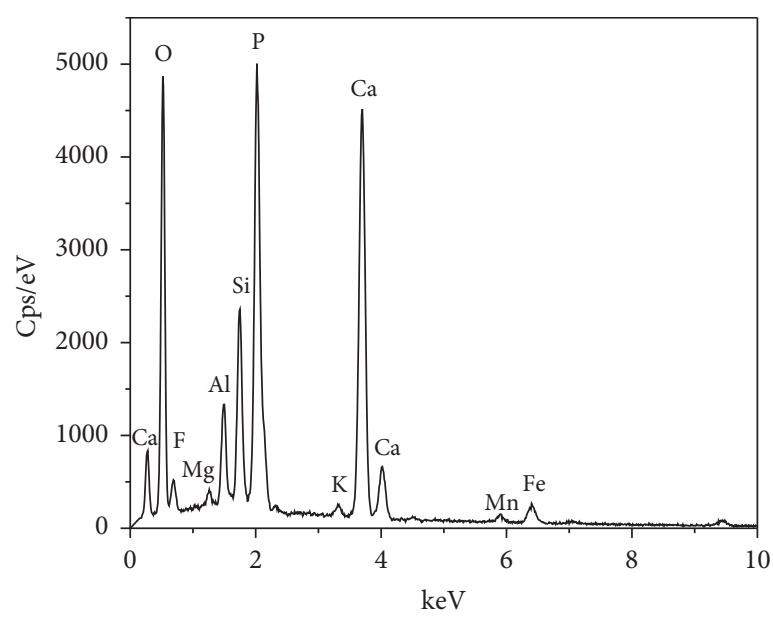

(a)

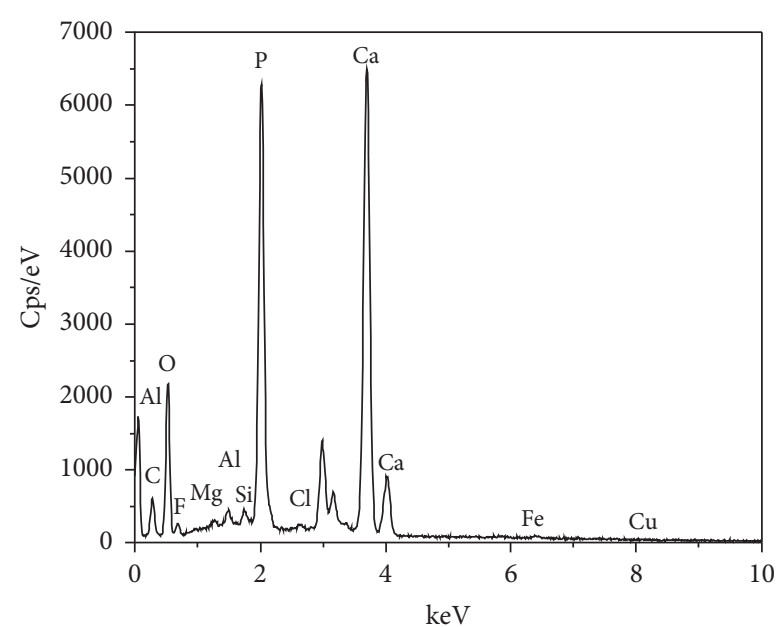

(b)

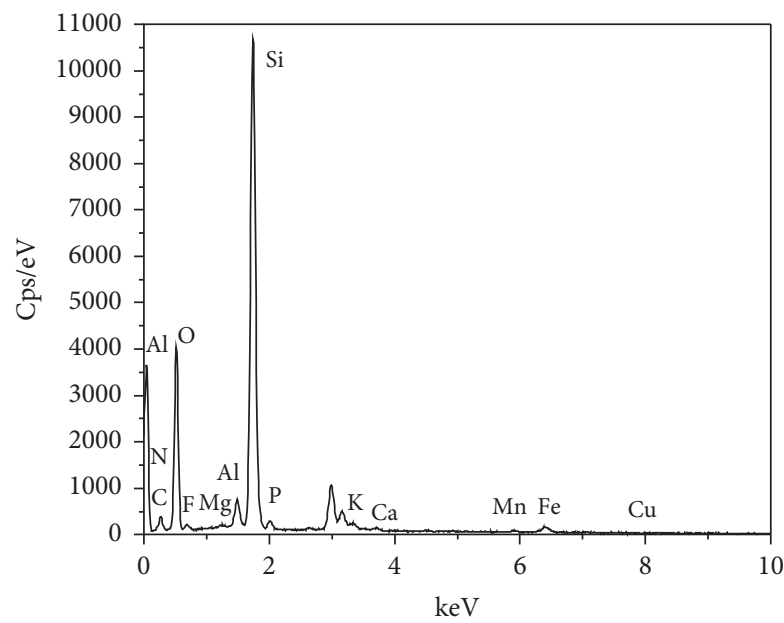

(c)

FIGURE 5: EDX spectra of apatite ore before and after modifying and the solid after filtering. (a) Apatite ore. (b) Modified apatite. (c) Solid after filtering.

TABLE 1: Composition of elements in apatite ore before and after modifying and the solid after filtering.

\begin{tabular}{lcccccc}
\hline & \multicolumn{3}{c}{ Apatite ore } & \multicolumn{2}{c}{$\begin{array}{c}\text { Modified } \\
\text { apatite }\end{array}$} & \multicolumn{2}{c}{$\begin{array}{c}\text { Solid after } \\
\text { filtering }\end{array}$} \\
& $\% m$ & $\% a$ & $\% m$ & $\% a$ & $\% m$ & $\% a$ \\
\hline $\mathrm{O}$ & 50.19 & 68.21 & 37.67 & 54.59 & 47.74 & 57.49 \\
$\mathrm{Ca}$ & 21.40 & 11.61 & 36.73 & 21.25 & 0.44 & 0.21 \\
$\mathrm{P}$ & 10.79 & 7.57 & 17.75 & 13.29 & 0.92 & 0.57 \\
$\mathrm{~F}$ & 2.76 & 3.16 & 2.58 & 3.15 & 1.07 & 1.08 \\
$\mathrm{Si}$ & 5.35 & 4.14 & 0.42 & 0.35 & 33.65 & 23.09 \\
$\mathrm{Al}$ & 3.06 & 2.47 & 0.46 & 0.40 & 1.69 & 1.21 \\
$\mathrm{Mn}$ & 1.19 & 0.47 & & & 0.80 & 0.28 \\
$\mathrm{Mg}$ & 0.36 & 0.32 & 0.17 & 0.16 & 0.11 & 0.09 \\
$\mathrm{~K}$ & 0.82 & 0.46 & & & 0.37 & 0.18 \\
$\mathrm{Fe}$ & 4.08 & 1.59 & 0.66 & 0.27 & 2.93 & 1.01 \\
$\mathrm{~N}$ & & & & & 6.91 & 9.50 \\
$\mathrm{C}$ & & & 3.34 & 6.44 & 3.28 & 5.26 \\
$\mathrm{Cu}$ & & & 0.16 & 0.06 & 0.11 & 0.03 \\
$\mathrm{Cl}$ & & & 0.07 & 0.04 & & \\
\hline
\end{tabular}

of $\mathrm{Cu}^{2+}, 45$ minutes was chosen for the removal process by the modified apatite ore. The adsorption efficiency and capacity of the $\mathrm{Cu}^{2+}$ treatment archives $85 \%$ and $41.34 \mathrm{mg} / \mathrm{g}$, respectively.

3.2.5. Effect of Initial Concentration of $\mathrm{Cd}^{2+}$ and $\mathrm{Cu}^{2+}$. Figure 11 shows the variation of adsorption efficiency and capacity according to the initial concentration of $\mathrm{Cd}^{2+}$ and $\mathrm{Cu}^{2+}$. It can be seen that the adsorption capacity increases, and the adsorption efficiency decreases with the increase of initial concentration. However, when the concentration increases to a certain value, the adsorption capacity is almost stable which corresponds to the adsorption process reaches the maximum state. It can be explained by the fact that an amount of modified apatite ore has a certain number of adsorption centers. When all adsorption centers are occupied by $\mathrm{Cd}^{2+}$ and $\mathrm{Cu}^{2+}$ ions, the ion concentration continues to increase, and the adsorption capacity is almost constant. 


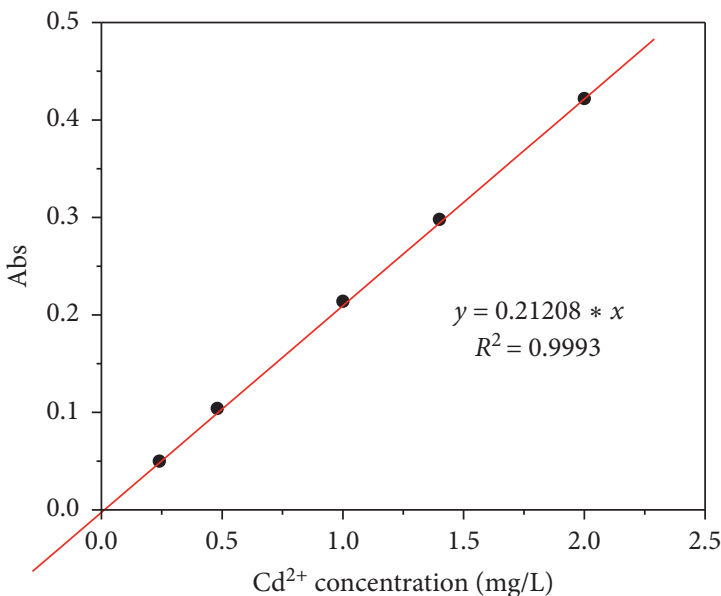

(a)

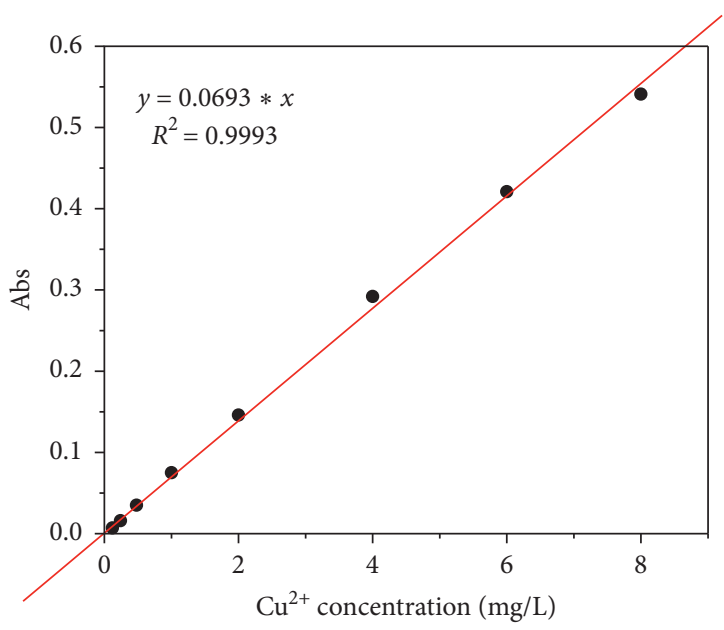

(b)

Figure 6: The calibration curves of $\mathrm{Cd}^{2+}$ and $\mathrm{Cu}^{2+}$.

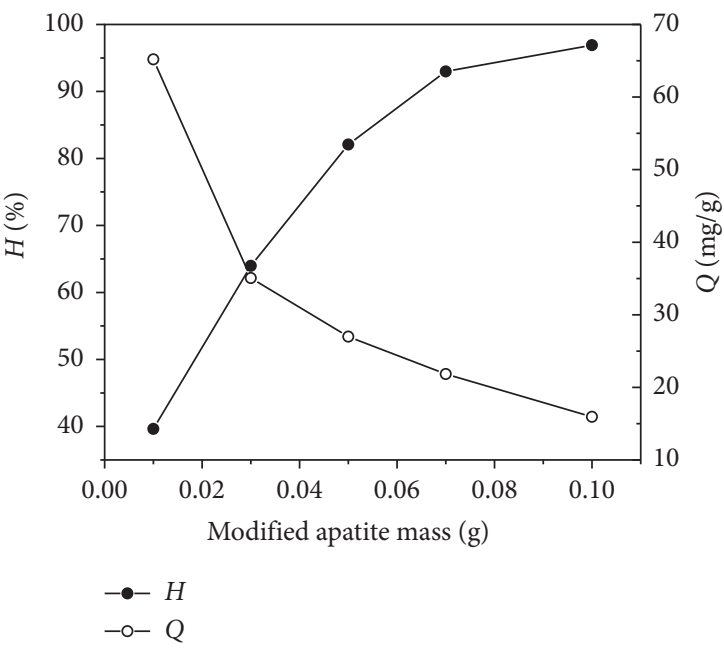

(a)

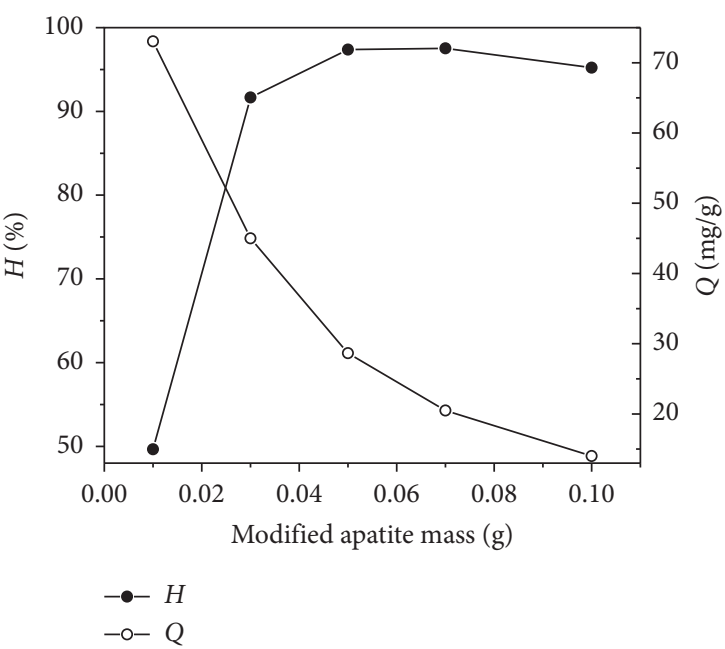

(b)

FIGURE 7: Variation of the $\mathrm{Cd}^{2+} / \mathrm{Cu}^{2+}$ adsorption capacity and efficiency according to the modified apatite ore mass at $\mathrm{pH}, C_{0}=30 \mathrm{mg} / \mathrm{L}$, $t=60$ mins. (a) $\mathrm{Cd}^{2+}$, (b) $\mathrm{Cu}^{2+}$.

3.2.6. Adsorption Isotherm. In order to determine the maximum adsorption capacity of modified apatite ore toward $\mathrm{Cd}^{2+}$ and $\mathrm{Cu}^{2+}$ ions, adsorption studies were carried out with conditions as follows: $0.05 \mathrm{~g}$ adsorbent with treatment $\mathrm{Cd}^{2+}$ and $0.03 \mathrm{~g}$ with $\mathrm{Cu}^{2+}$ was dispersed into $50 \mathrm{~mL}$ solution with different initial concentrations from 8.44 to $138.63 \mathrm{mg} / \mathrm{L}$ with $\mathrm{Cd}^{2+}, 17.68$ to $947.88 \mathrm{mg} / \mathrm{L}$ with $\mathrm{Cu}^{2+}$, at $25^{\circ} \mathrm{C}, \mathrm{pH}_{\mathrm{o}}$; the mixtures were stirred at $400 \mathrm{rpm}$ for 60 mins. Figures 12 and 13 show the linear fits of the experimental data of the $\mathrm{Cd}^{2+}$ or $\mathrm{Cu}^{2+}$ treatment process using Freundlich and Langmuir adsorption isotherm models.

From the obtained results, it is evident that Langmuir adsorption isotherm model can be used to describe experimental data of adsorption of $\mathrm{Cd}^{2+}$ and $\mathrm{Cu}^{2+}$. From the linear equation, the maximum adsorption capacity value $\left(Q_{\max }\right)$ of $\mathrm{Cd}^{2+}$ and $\mathrm{Cu}^{2+}$ is calculated at about 43.94 and $69.59 \mathrm{mg} / \mathrm{g}$, respectively. Compare with other adsorbents, with $\mathrm{Cd}^{2+}$,
HAp/CS, $81.1 \mathrm{mg} / \mathrm{g}$ [1], HAp, $21 \mathrm{~m}^{2} / \mathrm{g}, 16.7 \mathrm{mg} / \mathrm{g}$ [8], HAp, $94.9 \mathrm{~m}^{2} / \mathrm{g}, 142.9 \mathrm{mg} / \mathrm{g}$ [9], AlHAp, $205 \mathrm{~m}^{2} / \mathrm{g}, 103 \mathrm{mg} / \mathrm{g}$ [15], activated carbon, $178.5 \mathrm{mg} / \mathrm{g}$ [5], thiourea-modified Sorghum bicolor Agrowaste, $5.13 \mathrm{~m}^{2} / \mathrm{g}, 17.2 \mathrm{mg} / \mathrm{g}$ [35], with $\mathrm{Cu}^{2+}, \mathrm{HAp}, 50 \mathrm{~m}^{2} / \mathrm{g}, 96.6 \mathrm{mg} / \mathrm{g}$ [13], HAp, $125 \mathrm{mg} / \mathrm{g}$ [36], SDS modified laterite, $185 \mathrm{mg} / \mathrm{g}$ [2], Ni/Fe carbonate-fluorapatite, $74.5 \mathrm{~m}^{2} / \mathrm{g}, 147.5 \mathrm{mg} / \mathrm{g}$ [3], modified natural phosphate, $150 \mathrm{~m}^{2} / \mathrm{g}, 166 \mathrm{mg} / \mathrm{g}$, Bengurir rock-Morocco, $21 \mathrm{~m}^{2} / \mathrm{g}$, $57 \mathrm{mg} / \mathrm{g}$ [30], thiourea-modified Sorghum bicolor Agrowaste, $7.98 \mathrm{~m}^{2} / \mathrm{g}, 15.2 \mathrm{mg} / \mathrm{g}$ [35], we can conclude that modified apatite ore is a good adsorbent for $\mathrm{Cd}^{2+}$ and $\mathrm{Cu}^{2+}$.

3.2.7. The Phase Component and Molecular Structure of the Absorbent after Absorption. The X-ray diffraction patterns of modified apatite ore before and after $\mathrm{Cd}^{2+}$ adsorption (at $\mathrm{pH}_{0}, m=0.05 \mathrm{~g}, 30$ minutes, $\mathrm{Cd}^{2+}$ concentration of $30 \mathrm{mg} / \mathrm{L}$ ) 


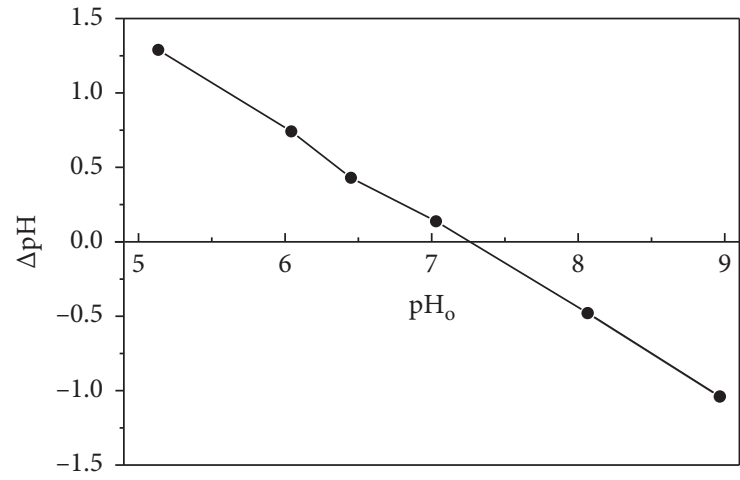

(a)

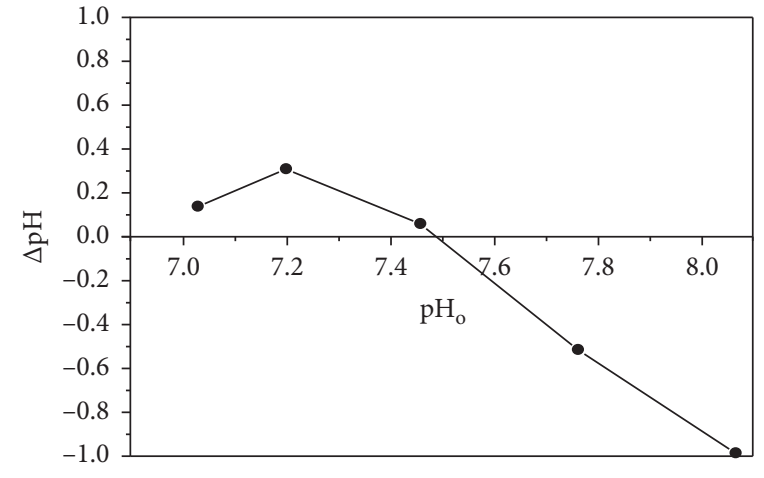

(b)

FIGURE 8: Graph for determining $\mathrm{pH}_{\mathrm{pzc}}$ of modified apatite in broad $\mathrm{pH}$ range (a) and in small $\mathrm{pH}$ range (b).

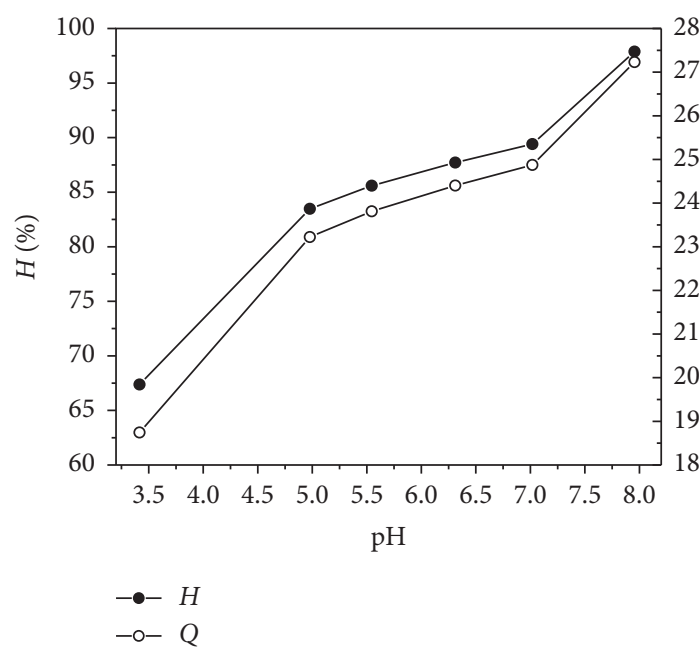

(a)

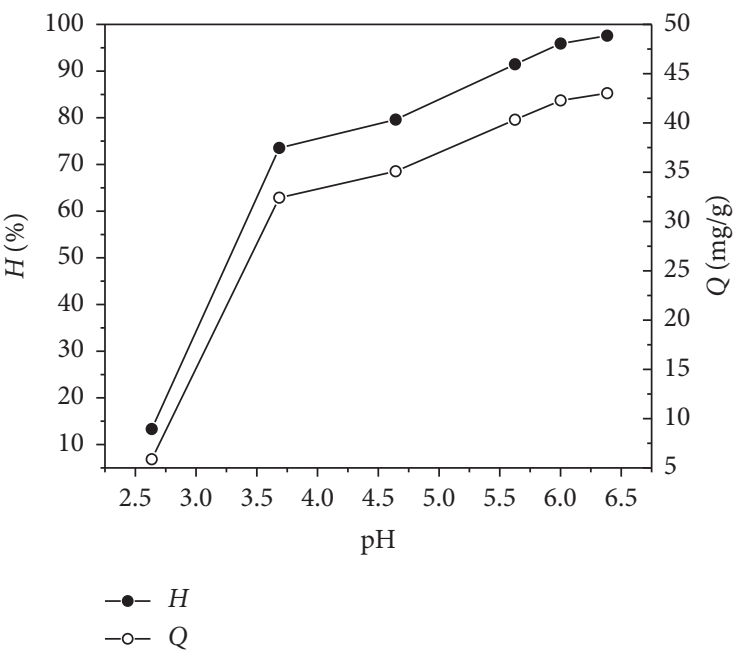

(b)

Figure 9: Effect of $\mathrm{pH}$ solution on the adsorption capacity and efficiency of $\mathrm{Cd}^{2+}$ ((a) 30 mins, $0.05 \mathrm{~g}$ modified apatite) and $\mathrm{Cu}^{2+}$ ((b) 45 mins, $0.03 \mathrm{~g}$ modified apatite) $\left(C_{\mathrm{o}}=30 \mathrm{mg} / \mathrm{L}\right)$.

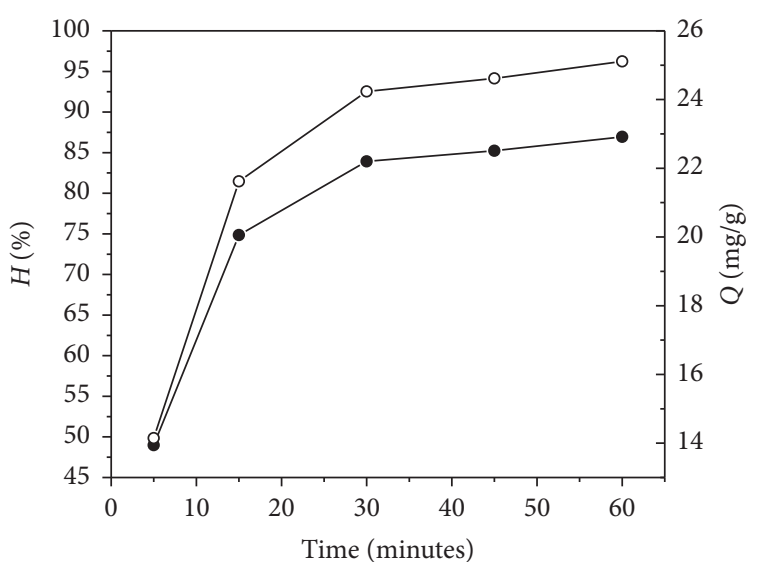

$-\bullet H$

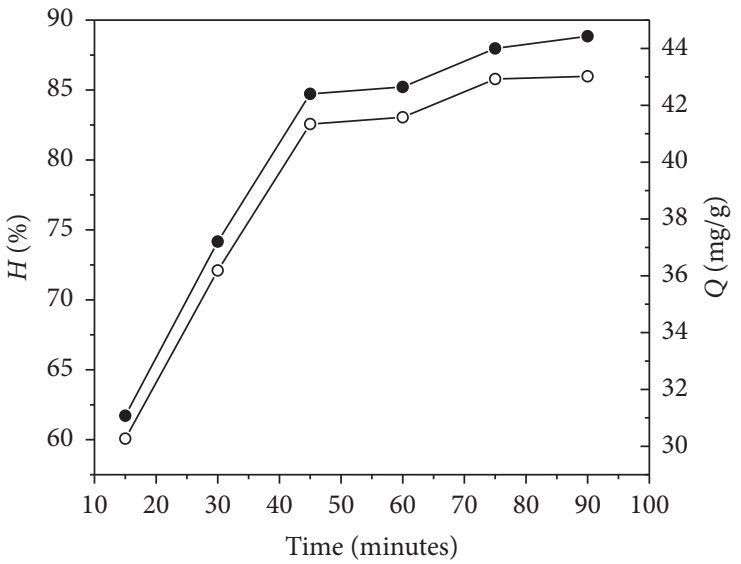

$-\bullet-H$

(a)

(b)

FIgURE 10: Variation of $\mathrm{Cd}^{2+}(\mathrm{a}), \mathrm{Cu}^{2+}$ (b) adsorption capacity, and efficiency of modified apatite ore according to the contact time. 


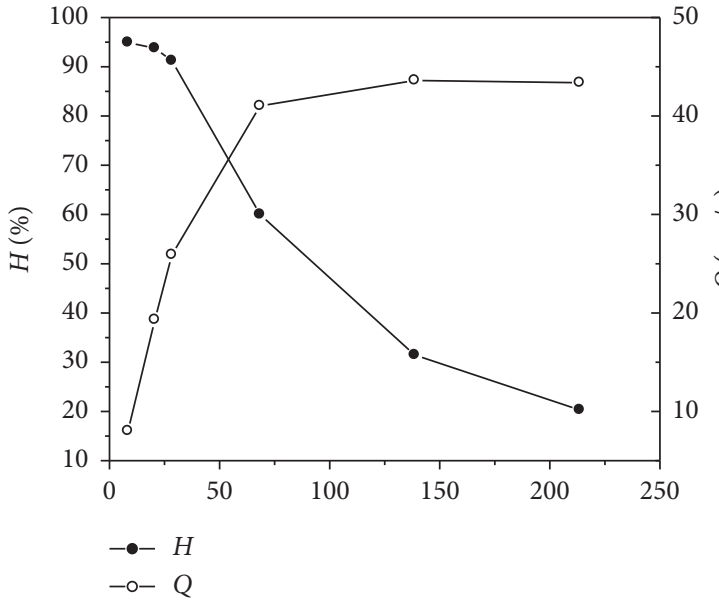

(a)

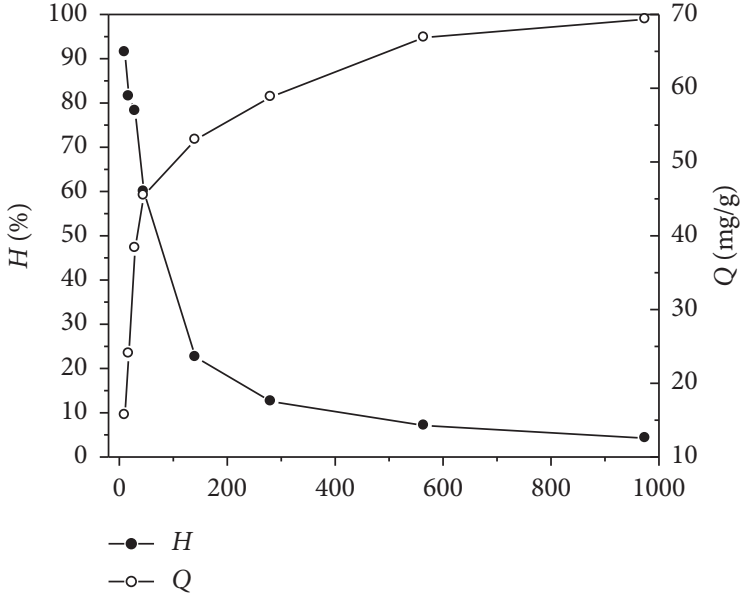

(b)

Figure 11: Variation of $\mathrm{Cd}^{2+}$ and $\mathrm{Cu}^{2+}$ adsorption capacity and efficiency of modified apatite ore according to the initial concentration $\left(\mathrm{pH}_{\mathrm{o}}, t=60 \mathrm{mins}\right)$. (a) $\mathrm{C} \mathrm{Cd}^{2+}(\mathrm{mg} / \mathrm{L})$, (b) $\mathrm{C} \mathrm{Cu}^{2+}(\mathrm{mg} / \mathrm{L})$.

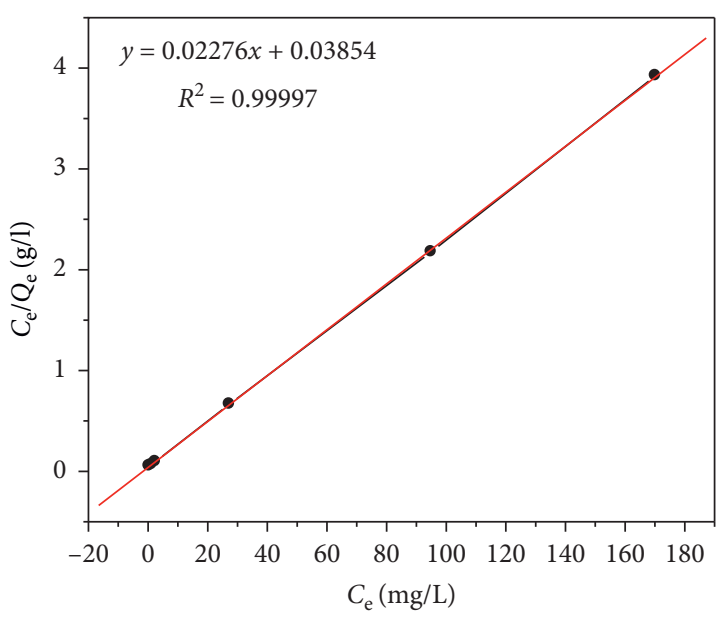

(a)

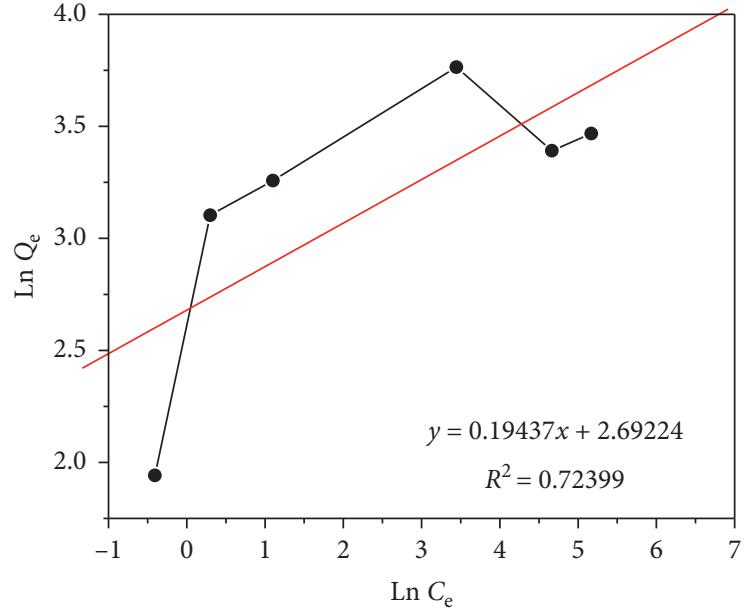

(b)

Figure 12: Adsorption isotherm curves of $\mathrm{Cd}^{2+}$ follow the Langmuir (a) and Freundlich (b).

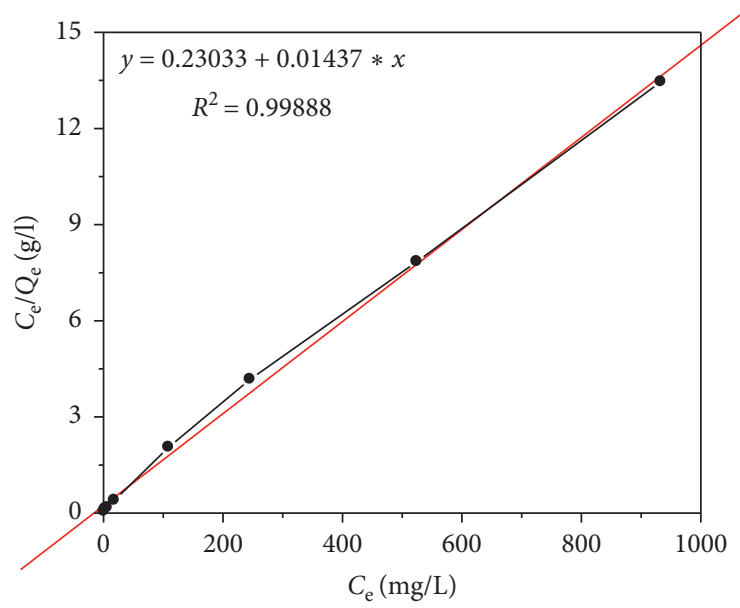

(a)

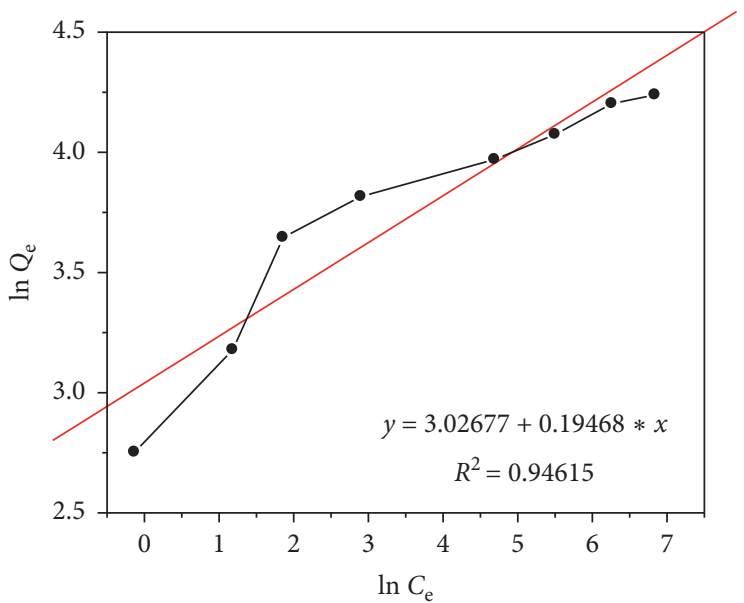

(b)

Figure 13: Adsorption isotherm curves of $\mathrm{Cu}^{2+}$ follow the Langmuir (a) and Freundlich (b). 


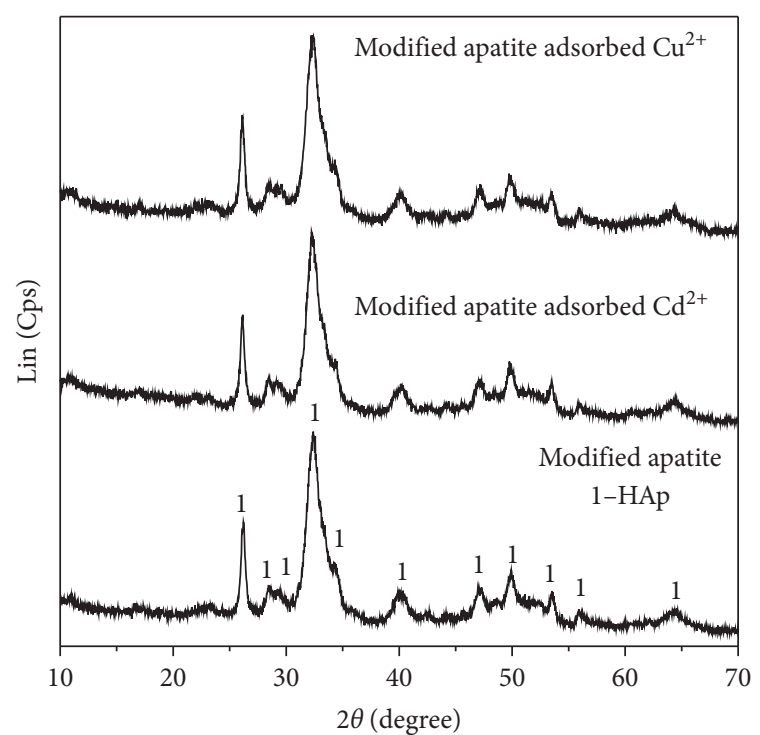

(a)

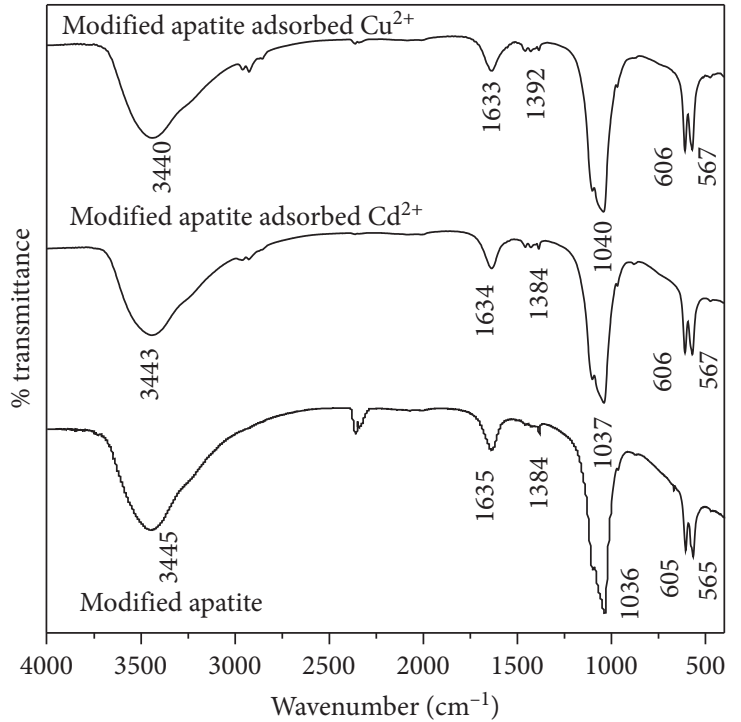

(b)

FIGURE 14: X-ray diffraction patterns (a) and IR spectra (b) of modified apatite ore before and after $\mathrm{Cd}^{2+}$ and $\mathrm{Cu}^{2+}$ adsorption.

and $\mathrm{Cu}^{2+}$ adsorption $\left(\mathrm{pH}_{0}, m=0.03 \mathrm{~g}, 45\right.$ minutes, $\mathrm{Cu}^{2+}$ concentration of $30 \mathrm{ppm}$ ) are shown in Figure 14(a). It can be seen that the material after adsorption still has the phase structure of hydroxyapatite, indicating that the phase structure of the material does not change.

The FTIR spectra of modified apatite ore before and after $\mathrm{Cd}^{2+}$ and $\mathrm{Cu}^{2+}$ adsorption are shown in Figure 14(b). FTIR spectra of the solid residues after adsorption are comparable to one of the initial modified apatite ore, suggesting no other functional groups formed after the heavy metal sorption. Compared with the FTIR spectra before and after adsorption of $\mathrm{Cd}^{2+}$ and $\mathrm{Cu}^{2+}$, there are band shifts, which occur in the groups of apatite that had bound metals. Sorption of $\mathrm{Cd}^{2+}$ and $\mathrm{Cu}^{2+}$ undergoes two-step processes. Rapid complexation of heavy metals on specific sites of the modified apatite ore surface is the first step. A metal diffusion into the modified apatite ore structure or to a heavy metal-containing modified apatite ore formation is the second step in the sorption process [36].

\section{Conclusions}

Apatite ore is modified by a chemical process using $\mathrm{HNO}_{3}$ and $\mathrm{NH}_{3}$. The modified apatite ore has the phase of nanohydroxyapatite with the specific surface area is $100.79 \mathrm{~m}^{2} / \mathrm{g}$ which increases about 25 times compared with apatite ore. $0.05 \mathrm{~g}$ modified apatite powder can remove about $84 \% \mathrm{Cd}^{2+}$ in $50 \mathrm{~mL} \mathrm{Cd}\left(\mathrm{NO}_{3}\right)_{2}$ solution of $30 \mathrm{mg} / \mathrm{l}$ with an adsorption capacity of $24.24 \mathrm{mg} / \mathrm{g}$. For treatment $\mathrm{Cu}^{2+}$ ions, $0.03 \mathrm{~g}$ modified apatite powder can remove about $85 \% \mathrm{Cu}^{2+}$ in $50 \mathrm{~mL} \mathrm{Cu}\left(\mathrm{NO}_{3}\right)_{2}$ solution of $30 \mathrm{mg} / \mathrm{L}$ with an adsorption capacity of $41.58 \mathrm{mg} / \mathrm{g}$. Both $\mathrm{Cd}^{2+}$ and $\mathrm{Cu}^{2+}$ removal process is best described by the Langmuir adsorption isotherm model with the $R^{2}$ near $1\left(R^{2}=0.99997\right.$ and 0.99888 , respectively). The maximum monolayer adsorption capacity is calculated from the Langmuir adsorption isotherm about 43.94 and $69.59 \mathrm{mg} / \mathrm{g}$ for $\mathrm{Cd}^{2+}$ and $\mathrm{Cu}^{2+}$, respectively.

\section{Data Availability}

The data used to support the findings of this study are included within the article.

\section{Conflicts of Interest}

The authors declare that they have no conflicts of interest.

\section{Acknowledgments}

This research was funded by the Institute of Tropical Technology (ITT), Vietnam Academy of Science and Technology (VAST) with grant no. VAST07.02/20-21.

\section{References}

[1] S. Park, A. Gomez-Flores, Y. S. Chung, and H. Kim, "Removal of cadmium and lead from aqueous solution by hydroxyapatite/chitosan hybrid fibrous sorbent: kinetics and equilibrium studies," Journal of Chemistry, vol. 2015, Article ID 396290, 12 pages, 2015.

[2] T. D. Pham, H. H. Nguyen, N. V. Nguyen et al., "Adsorptive removal of copper by using surfactant modified laterite soil," Journal of Chemistry, vol. 2017, Article ID 1986071, p. 10, 2017.

[3] M. R. Abukhadra, F. M. Dardir, M. Shaban, E. A. Ahmed, and M. F. Soliman, "Superior removal of $\mathrm{Co}^{2+}, \mathrm{Cu}^{2+}$ and $\mathrm{Zn}^{2+}$ contaminants from water utilizing spongy $\mathrm{Ni} / \mathrm{Fe}$ carbonatefluorapatite; preparation, application and mechanism," Ecotoxicology and Environmental Safety, vol. 157, pp. 358-368, 2018.

[4] WHO, Guidelines for Drinking-Water Quality, WHO, Geneva, Switzerland, 2006.

[5] M. Karnib, A. Kabbani, H. Holail, and Z. Olama, "Heavy metals removal using activated carbon, silica and silica activated carbon composite," Energy Procedia, vol. 50, pp. 113-120, 2014.

[6] A. Corami, S. Mignardi, and V. Ferrini, "Cadmium removal from single- and multi-metal $(\mathrm{Cd}+\mathrm{Pb}+\mathrm{Zn}+\mathrm{Cu})$ solutions by 
sorption on hydroxyapatite," Journal of Colloid and Interface Science, vol. 317, no. 2, pp. 402-408, 2008.

[7] N. Gupta, A. K. Kushwaha, and M. C. Chattopadhyaya, "Adsorptive removal of $\mathrm{Pb}^{2+}, \mathrm{Co}^{2+}$ and $\mathrm{Ni}^{2+}$ by hydroxyapatite/chitosan composite from aqueous solution," Journal of the Taiwan Institute of Chemical Engineers, vol. 43, pp. 125131, 2012.

[8] I. D. Smiciklas, S. K. Milonjic', P. Pfendt, and S. Raicevic', "The point of zero charge and sorption of cadmium (II) and strontium (II) ions on synthetic hydroxyapatite," Separation and Purification Technology, vol. 18, pp. 185-194, 2009.

[9] I. Mobasherpour, E. Salahi, and M. Pazouki, "Comparative of the removal of $\mathrm{Pb}^{2+}, \mathrm{Cd}^{2+}$ and $\mathrm{Ni}^{2+}$ by nano crystallite hydroxyapatite from aqueous solutions: adsorption isotherm study," Arabian Journal of Chemistry, vol. 5, no. 4, pp. 439446, 2012.

[10] L. Dong, Z. Zhu, Y. Qiu, and J. Zhao, "Removal of lead from aqueous solution by hydroxyapatite/magnetite composite adsorbent," Chemical Engineering Journal, vol. 165, no. 3, pp. 827-834, 2010.

[11] R. R. Sheha, "Sorption behavior of $\mathrm{Zn}$ (II) ions on synthesized hydroxyapatites," Journal of Colloid and Interface Science, vol. 310, no. 1, pp. 18-26, 2007.

[12] V. T. Phuong, P. T. Nam, N. T. Phuong, D. T. Hai, and D. T. M. Thanh, "Defluoridation behavior of nano Zn-hydroxyapatite synthesized by chemical precipitation method," Vietnam Journal of Chemistry, vol. 50, no. 6B, pp. 239-244, 2012.

[13] A. Corami, F. D’Acapito, S. Mignardi, and V. Ferrini, "Removal of $\mathrm{Cu}$ from aqueous solutions by synthetic hydroxyapatite: EXAFS investigation," Materials Science and Engineering: B, vol. 149, no. 2, pp. 209-213, 2008.

[14] W.-Q. Tang, R.-Y. Zeng, Y.-L. Feng et al., "Removal of Cr(VI) from aqueous solution by nano-carbonate hydroxylapatite of different $\mathrm{Ca} / \mathrm{P}$ molar ratios," Chemical Engineering Journal, vol. 223, pp. 340-346, 2013.

[15] N. T. Thom, D. T. Mai Thanh, P. T. Nam et al., "Treatment of $\mathrm{Cd}^{2+}$ ions using aluminum doped hydroxyapatite (AlHAp) powder," Vietnam Journal of Chemistry, vol. 55, no. 4, pp. 393-399, 2017.

[16] L. T. Duyen, L. T. P. Thao, D. T. Hai et al., "Fabrication of porous hydroxyapatite granules as an effective adsorbent for the removal of aqueous $\mathrm{Pb}(\mathrm{II})$ ions," Journal of Chemistry, vol. 2019, Article ID 8620181, 10 pages, 2019.

[17] F. Granados-Correa, J. Vilchis-Granados, M. Jiménez-Reyes, and L. A. Quiroz-Granados, "Adsorption behaviour of La(III) and $\mathrm{Eu}(\mathrm{III})$ ions from aqueous solutions by hydroxyapatite: kinetic, isotherm, and thermodynamic studies," Journal of Chemistry, vol. 2013, Article ID 751696, 9 pages, 2013.

[18] H. Hou, R. Zhou, P. Wu, and L. Wu, "Removal of Congo red dye from aqueous solution with hydroxyapatite/chitosan composite," Chemical Engineering Journal, vol. 211-212, pp. 336-342, 2012.

[19] M. Shaban, M. R. Abukhadra, A. S. Mohamed, M. G. Shahien, and S. S. Ibrahim, "Synthesis of mesoporous graphite functionalized by nitrogen for efficient removal of safranin dye utilizing rice husk ash; equilibrium studies and response surface optimization," Journal of Inorganic and Organometallic Polymers and Materials, vol. 28, no. 1, pp. 279-294, 2018.

[20] M. Shaban, M. I. Sayed, M. G. Shahien, M. R. Abukhadra, and Z. M. Ahmed, "Adsorption behavior of inorganic- and organic-modified kaolinite for congo red dye from water, kinetic modeling, and equilibrium studies," Journal of Sol-Gel Science and Technology, vol. 87, no. 2, pp. 427-441, 2018.
[21] M. R. Abukhadra and M. Mostafa, "Effective decontamination of phosphate and ammonium utilizing novel muscovite/ phillipsite composite; equilibrium investigation and realistic application," Science of the Total Environment, vol. 667, pp. 101-111, 2019.

[22] W. D. Bostick, R. J. Jarabek, and J. L. Conca, "PhosphateInduced Metal Stabilization: Use of Apatite and Bone Char for the Removal of Soluble Radionuclides in Authentic and Simulated DOE Groundwater," in Proceedings of the Air and Waste 92nd Annual Meeting and Exhibition, St. Louis, MO, USA, 1999.

[23] W. D. Bostick, "Use of apatite for chemical stabilization of subsurface contaminants," Final Report of Contract: DEAC26-01NT41306 of U.S. Department of Energy, National Energy Technology Laboratory, New York, NY, USA, 2003.

[24] R. J. Martinez, M. J. Beazley, and P. A. Sobecky, "Phosphatemediated remediation of metals and radionuclides," Advances in Ecology, vol. 2014, Article ID 786929, 14 pages, 2014.

[25] J. L. Conca, N. Lu, G. Parker, B. Moore, and A. Adams, "PIMS-remediation of metal contamninated waters and soils," in Proceedings of the Second International Conference on Remediation of Chlorinated and Recalcitrant Compounds, May (2000) with an Addendum from ICAM, Montery, CA, USA, 2000.

[26] B. M. Thomson, C. L. Smith, R. D. Busch, M. D. Siegel, and C. Baldwin, "Removal of metals and radionuclides using apatite and other natural sorbents," Journal of Environmental Engineering, vol. 129, no. 6, pp. 492-499, 2003.

[27] N. T. Basta and S. L. McGowen, "Evaluation of chemical immobilization treatments for reducing heavy metal transport in a smelter-contaminated soil," Environmental Pollution, vol. 127, no. 1, pp. 73-82, 2004.

[28] C. James, Phosphate - Induced Metal Stabilization, Report of Contract: 68D60023 of United States Environmental Protection Agency, 1997.

[29] J. L. Conca and J. Wright, "An apatite II permeable reactive barrier to remediate groundwater containing $\mathrm{Zn}, \mathrm{Pb}$ and $\mathrm{Cd}$," Applied Geochemistry, vol. 21, pp. 1288-1300, 2006.

[30] S. E. Asri, A. Laghzizil, T. Coradin, A. Saoiabi, A. Alaoui, and R. M'hamedi, "Conversion of natural phosphate rock into mesoporous hydroxyapatite for heavy metals removal from aqueous solution," Colloids and Surfaces A: Physicochemical and Engineering Aspects, vol. 362, no. 1-3, pp. 33-38, 2010.

[31] S. E. Asri, A. Laghzizil, A. Saoiabi et al., "A novel process for the fabrication of nanoporous apatites from Moroccan phosphate rock," Colloids and Surfaces A: Physicochemical Engineering Aspects, vol. 350, no. 1-3, pp. 73-78, 2009.

[32] I. Nikčević, V. Jokanovic', M. Mitric', Z. Nedic', D. Makovec, and D. Uskokovic, "Mechanochemical synthesis of nanostructured fluorapatite/fluorhydroxyapatite and carbonated fluorapatite/fluorhydroxyapatite," Journal of Solid State Chemistry, vol. 177, pp. 2565-2574, 2004.

[33] J. Wang, Y. Chao, Q. Wan, Z. Zhu, and H. Yu, "Fluoridated hydroxyapatite coatings on titanium obtained by electrochemical deposition," Acta Biomaterialia, vol. 5, no. 5, pp. 1798-1807, 2009.

[34] V. T. Hanh, P. T. Nam, N. T. Phuong, and D. T. M. Thanh, "Electrodeposition of co-doped hydroxyapatite coating on 316L stainless steel," Vietnam Journal of Science and Technology, vol. 56, no. 1, pp. 94-101, 2018.

[35] M. Salman, R. Rehman, U. Farooq, A. Tahir, and L. Mitu, "Biosorptive removal of cadmium(II) and copper(II) using microwave-assisted thiourea-modified sorghum bicolor 
agrowaste," Journal of Chemistry, vol. 2020, Article ID 8269643, 11 pages, 2020.

[36] S. T. Ramesh, N. Rameshbabu, R. Gandhimathi, P. V. Nidheesh, and M. Srikanth Kumar, "Kinetics and equilibrium studies for the removal of heavy metals in both single and binary systems using hydroxyapatite," Applied Water Science, vol. 2, no. 3, pp. 187-197, 2012. 